\title{
How best to describe the episcopal miter?
}

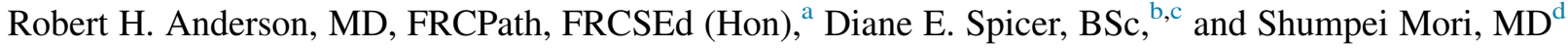

\author{
From the ${ }^{\mathrm{a} I n s t i t u t e}$ of Genetic Medicine, Newcastle University, Newcastle-upon-Tyne, United Kingdom; ${ }^{\mathrm{b}}$ Depart- \\ ment of Pediatric Cardiology, University of Florida, Gainesville, Fla; 'Johns Hopkins All Children's Heart \\ Institute, St Petersburg, Fla; and division of Cardiovascular Medicine, Department of Internal Medicine, \\ Kobe University Graduate School of Medicine, Kobe, Japan. \\ Disclosures: Authors have nothing to disclose with regard to commercial support. \\ Received for publication Aug 13, 2017; accepted for publication Aug 19, 2017; available ahead of print Sept 26, \\ 2017. \\ Address for reprints: Robert H. Anderson, MD, FRCPath, FRCSEd (Hon), 60 Earlsfield Rd, London SW18 3DN, \\ United Kingdom (E-mail: sejjran@ucl.ac.uk). \\ J Thorac Cardiovasc Surg 2017;154:1936-7 \\ $0022-5223 / \$ 36.00$ \\ Copyright $(2017$ by The American Association for Thoracic Surgery \\ http://dx.doi.org/10.1016/j.jtcvs.2017.08.062
}

The descriptions of the mitral valve provided by the group working in Krakow ${ }^{1}$ are largely in keeping with our own, as summarized in the images and drawings provided in the fourth edition of Wilcox's Surgical Anatomy of the Heart. $^{2}$ Inspection from the atrial aspect shows how the components of the skirt of leaflet tissue guarding the left atrioventricular junction close along a solitary zone of apposition. It was more likely the view of the valve from the ventricular aspect, however, that prompted our forebears to liken it to the episcopal mitre.

As the group from Krakow ${ }^{1}$ conclude, it is sufficient to identify 2 components within this skirt of leaflet tissue, which are better termed "leaflets" than "cusps." Endorsing the observations of Carpentier and colleagues, ${ }^{3}$ they describe how the mural leaflet is usually divided into the

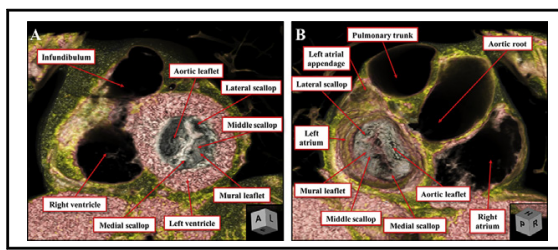

The details of the mitral valvar components as revealed by computed tomography.

\section{Central Message}

The atrioventricular valve guarding the normal left atrioventricular junction is named because of its likeness to the episcopal miter. Its 2 leaflets close along a solitary zone of apposition.

See Article page 1927.

so-called scallops, with anatomic variation reflecting the presence of accessory scallops, found in just less than one third of their specimens. The Polish investigators correctly describe the ends of the solitary zone of apposition as being positioned superolaterally and inferomedially within the left ventricle. The current approach of describing these so-called commissures as being "posteromedial" and "anterolateral" is appropriate only when the heart is removed from the body and viewed in the "Valentine"
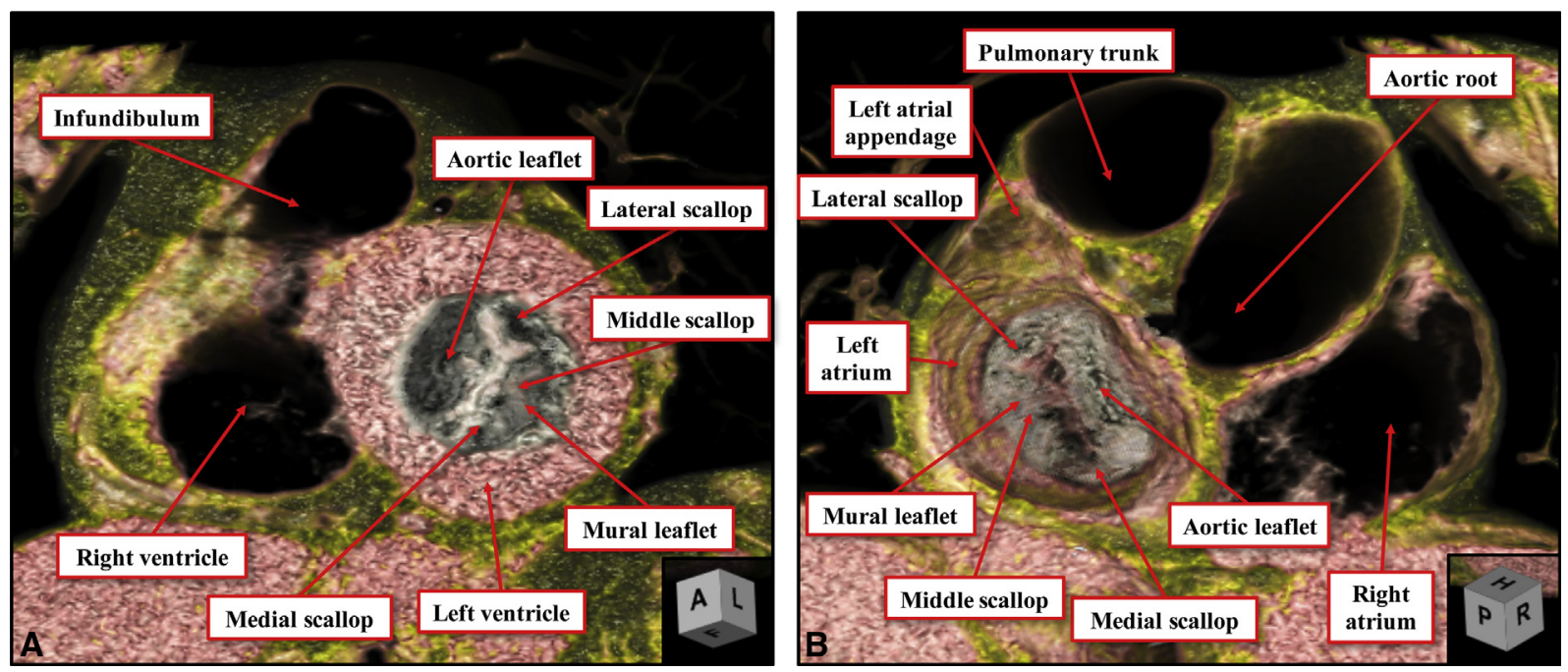

FIGURE 1. The images show the details of the anatomy of the mitral valve as revealed using multi-detector row computed tomography. The left hand panel shows the view as seen from the ventricular apex, while the right hand panel shows the view from the atrial aspect. Note the solitary zone of apposition between the aortic and mural leaflets of the valve. If using standard anatomical definitions, this solitary zone of apposition should be defined as the "commissure". It is usually the ends of the zone of apposition, however, that are defined in this fashion. Note also that, when seen in attitudinally appropriate fashion, the ends of the zone of apposition are located infero-septally and supero-laterally. It is a mistake to describe these positions as being postero-medial and antero-lateral. 
position. ${ }^{4}$ Investigative techniques showing the heart as it lies within the body (Figure 1) now point to the need for the attitudinally appropriate approach.

It is a pity that the Polish investigators continue to describe the ends of the zone of apposition as "commissures." When used anatomically in regard to the lips or the eyelids, the commissure describes the zone of apposition between the moving parts. Logic dictates that the word should be used in comparable fashion when describing the mitral valve. During the process of review, when seeking to maintain conventional wisdom by describing the ends of the zone of apposition as paired "commissures," the authors cited a definition from a dictionary of medicine. This stated that the "commissure" is "the site of junction between adjacent cusps of a cardiac valve." $"$ But does not this definition describe the length of the solitary zone of apposition, rather than its ends?

Irrespective of such niceties of description, the leaflets of the normal mitral valve do close along a solitary zone of apposition. And the ends of this line, as correctly emphasized by the Polish investigators, do not reach to the valvar annulus. It is the leaflet tissue at the ends of the zone of apposition that some describe as the commissural leaflets. In the autopsy room, the valvar components are best visualized when the valvar orifice is opened. The availability of the new diagnostic techniques now shows that all the details described by the group from Krakow ${ }^{1}$ can equally well be seen during life. This will permit direct inspection of the components of not only the normal valve but also the diseased valve. Such virtual dissection should now permit us to provide the key surgical details regarding the anatomic components of the mitral valve.

\section{References}

1. Krawczyk-Ożóg A, Hołda MK, Sorysz D, Koziej M, Siudak Z, Dudek D, et al. Morphological variability of the mitral valve leaflets. J Thorac Cardiovasc Surg. 2017;154:1927-35.

2. Anderson RH, Spicer DE, Hlavacek AM, Cook AC, Backer CL. Wilcox's Surgical Anatomy of the Heart. 4th ed. Cambridge, UK: Cambridge University Press; 2013; 66-70.

3. Carpentier A, Branchini B, Cour JC, Asfaou E, Villani M, Deloche A, et al. Congenital malformations of the mitral valve in children. Pathology and surgical treatment. J Thorac Cardiovasc Surg. 1976;72:854-66.

4. Anderson RH, Loukas M. The importance of attitudinally appropriate description of cardiac anatomy. Clin Anat. 2009;22:47-51.

5. Miller-Keane Encyclopedia and Dictionary of Medicine, Nursing, and Allied Health. 7th ed. Philadelphia, PA: WB Saunders; 2003. 